\title{
IN-VITRO STUDY ON FERMENTATION CHARACTERISTICS OF DIFFERENT HULLESS BARLEY CULTIVAR FLAKES
}

\author{
Kristīne Majore $^{1, \#}$, Vita Šterna ${ }^{2}$, Māra Bleidere ${ }^{2}$, Sanita Reidzāne ${ }^{1}$, and Inga Ciproviča ${ }^{1}$ \\ ${ }^{1}$ Faculty of Food Technology, Latvia University of Life Sciences and Technologies, 2 Lielā Str., Jelgava, LV-3001, LATVIA \\ 2 Department of Plant Breeding and Agroecology, Institute of Agroresources and Economics, "Dižzemes", Dižstende, \\ Libagi civil parish, Talsi Municipality, LV-3258, LATVIA \\ \# Corresponding author, kristine_majore@inbox.Iv
}

Contributed by Inga Ciproviča

\begin{abstract}
Barley (Hordium vulgare L.) grain is an important food ingredient due to the presence of essential compounds like $\beta$-glucans, proteins, resistant starch, phenolic compounds etc. $\beta$-glucans are able to lower cholesterol level in blood plasma and the glycaemic index, to enhance lipid metabolism and to reduce the risk of colon cancer. Hulless barley cultivars are more suitable to the human diet, because the hulls can be easily removed, as well as minimal grain processing in food production contributes to the full benefit of the whole grain. Several studies show that hulless grains have a higher digestible energy, and they have higher protein content compared to hulled grains. Different cultivars have unique composition and physical properties. The hulless barley cultivars are less studied than hulled barley and oats. The aim of this study was to evaluate the fermentation characteristics of flakes of different hulless barley cultivars in vitro and to analyse the fermentation pattern of $\beta$-glucans and proteins. Samples of six hulless barley cultivar flakes with different $\beta$-glucan (4.17-6.59\%), soluble dietary fibre (18.1-32.0\%) and resistant starch (0.74-10.65\%) content were boiled in water $10 \mathrm{~min}$, and the obtained porridge samples were treated under in vitro fementation conditions. The concentration of fermented porridge solids as well as $\beta$-glucans and proteins was measured. The concentration of undigested solids varied from 38.3 to $61.0 \%$ depending on barley cultivar. The concentration of protein was not significantly changed, but $\beta$-glucan concentration was significantly decreased after in vitro digestion comparing to indigestible samples.
\end{abstract}

Keywords: grain in vitro digestion, porridge solids, $\beta$-glucans, protein, resistant starch.

\section{INTRODUCTION}

Different hulless barley cultivars have unique composition and physical properties. Hulless barley cultivars compared to hulled cultivars have increased nutritional value due to higher content of proteins (Ehrenbergerova et al., 2003; Biel et al., 2009), $\beta$-glucans (Izydorczyk et al., 2008) and soluble dietary fibre (Baik, Ullrich, 2008; Sterna et al., 2017).

Soluble fibre $\beta$-glucans have been widely studied. Among the benefits to humans from glucans reported in literature are prevention of various diet-related diseases, such as diabetes and cardiovascular diseases (Kalra and Jood, 2001; Jenkins et al. 2002), reduction of serum cholesterol level (Ahmad et al., 2009; 2012), lower of colon cancer risk
(Dongovski et al., 2002; Rose et al., 2007), etc. $\beta$-glucans can also reduce postmeal blood glucose response and lower the cholesterol level, increase digested food viscosity in the small intestines (Wood, 2002), and the fermentability of $\beta$-glucans, which are additional health benefits. At least $3 \mathrm{~g}$ of $\beta$-glucan is recommended daily to achieve a positive effect on human health (FDA, 2005; EFSA, 2008).

A new consumer-driven food market requires barley cultivars with a high level of total dietary fibre, $\beta$-glucans, phenolic acids and lower amount of starch. For example, the hulless barley varieties in Canada that are recommended for human consumption are mainly characterised by altered starch composition, which is either waxy endosperm or highly (about 40\%) resistant starch. Genetically, such varieties are usually characterised by elevated $\beta$-glucan content 
in barley grains (Ames et al., 2006; Izydorczyk et al., 2014). The main proteins in barley endosperm are hordein $(35-45 \%)$ and glutelin $(35-45 \%)$. Barley protein fractions may have different functional properties due to different molecular structures (Wang et al., 2010).

In vitro methods that simulate digestion processes are widely used to address scientific questions like as the digestibility and bioaccessibility of macronutrients like proteins, carbohydrates, lipids, and micronutrients. Simulated digestion methods typically include the oral, gastric, and small intestinal phases, and in some cases also large intestinal fermentation. In vitro methods are more rapid, less expensive, less labour intensive, and do not have ethical restrictions. In vitro models are useful to study digestion of single substrates or simple meals under specific conditions (Minekus et al., 2014).

Hulless barley is still a less studied cereals, in comparison with hulled barley and oats. Therefore, the aim of this study was to evaluate the fermentation characteristics of different barley cultivar flakes in vitro and to determine the fermentation pattern of $\beta$-glucans and proteins.

\section{MATERIAL AND METHODS}

Hulless barley (Hordium vulgare L.) cultivars 'Pihl' (Norway), 'Gawrozs' (Poland), 'Kornelija' (Latvia), 'Irbe' (Latvia), the high amylose cultivar 'CDC Hilose' (Canada) and low amylose (waxy) cultivar 'CDC Ascent' (Canada) were used in the study. The barley was grown at Stende (lat. $57.1412^{\circ} \mathrm{N}$, long. $22.5367^{\circ} \mathrm{E}$ ) and harvested in 2020 . Harvested and dried grains were cleaned using a PETKUS cleaner (Germany) with longitudinal sieves $(2.2 \times 20 \mathrm{~mm})$. Barley flakes were made with grain flaking equipment MARGA Mulino (Marcato, Italy).

Chemicals used for digestion process simulation $(\mathrm{KCl}$, $\mathrm{KH}_{2} \mathrm{PO}_{4}, \mathrm{NaHCO}_{3}, \mathrm{NaCl}, \mathrm{MgCl}_{2}\left(\mathrm{H}_{2} \mathrm{O}\right)_{6},\left(\mathrm{NH}_{4}\right)_{2} \mathrm{CO}_{3}$, $\mathrm{NaOH}, \mathrm{HCl}, \mathrm{CaCl}_{2}$, bile salt, porcine pepsin (EC 3.4.23.1), porcine trypsin (EC 3.4.21.4), bovine chymotrypsin (EC 3.4.21.1), porcine pancreatic $\alpha$-amylase (EC 3.2.1.1), porcine pancreatic lipase (EC 3.1.1.3), porcine pancreatic colipase (EC 259-490-1)) were purchased from SigmaAldrich (Riga, Latvia).

The chemical analysis of hulless barley flakes was carried out at the Laboratory of Grain Technology and Agricultural Chemistry of the Institute of Agroresources and Economics. Collected flake samples were dried at $60{ }^{\circ} \mathrm{C}$, ground in a mill with a $1.0 \mathrm{~mm}$ sieve. Protein content was determined by the Kjeldahl method, and conversion factor 6.2 was used for protein calculation. Lipids were extracted with petroleum ether (boiling range of $40-60{ }^{\circ} \mathrm{C}$ ) by the Soxhlet extraction method and further determined gravimetrically. Content of starch was determined by LVS EN ISO 10520:2001 (Native starch - Determination of starch content - Ewers Polarimetric Method). Content of $\beta$-glucans was determined according to the ICC Standard Method No. 168 using Assay kits (Megazyme Ltd, Ireland). The content of resistant starch was determined using the Resistant starch kit K-RSTAR (Megazyme Ltd, Ireland) according to AOAC Official Method 2002.02; AACC Method 32-40.01. Dietary fibre was determined by the AOAC 991.43:1994 method (Total, Soluble, and Insoluble Dietary Fibre in Foods).

In-vitro digestion method. The experiment was carried out to determine the effect of the simulated digestion on barley cultivar flakes porridge using the Minekus et al., (2014) method with some modifications. Porridge was prepared using $30 \mathrm{~g}$ hulless barley flakes and $120 \mathrm{ml}$ water, boiling 10 minutes in a pot with a lid. Dry matter content of porridge was determined prior to analysis. The digestive process affects proteins, $\beta$-glucans, soluble and insoluble dietary fibre and resistant starch; their content in the tested porridge sample was calculated based on the dry matter content.

The chosen simulated digestion method included gastric and small intestinal phases and Labfors 5, INFORS HT (Bottmingen, Switzerland) was used for enzymatical digestion. $30 \mathrm{~g}$ of porridge sample was tested. The sample was mixed with $24 \mathrm{ml}$ of simulated salivary fluid (SSF) electrolyte solution and with $0.15 \mathrm{ml}$ of $0.3 \mathrm{M} \mathrm{CaCl}_{2}$ for $2 \mathrm{~min}$ at $37{ }^{\circ} \mathrm{C}$, then $55 \mathrm{ml}$ of simulated gastric fluid (SGF) and $0.03 \mathrm{ml}$ of $0.3 \mathrm{M} \mathrm{CaCl}_{2}$ were added and $\mathrm{pH}$ was adjusted till $2.9 \pm 0.1$ using $1 \mathrm{M} \mathrm{HCl}$ and $0.96 \mathrm{~g}$ of pepsin was added. Then the mixture was continuously mixed at $120 \mathrm{rpm}$ for $2 \mathrm{~h}$ at 37 ${ }^{\circ} \mathrm{C}$. After gastric digestion simulation, $110 \mathrm{ml}$ of simulated intestinal fluid (SIF) and $0.24 \mathrm{ml}$ of $0.3 \mathrm{M} \mathrm{CaCl}_{2}$ were added and $\mathrm{pH}$ was adjusted till $7 \pm 0.1$ using $1 \mathrm{M} \mathrm{NaHCO}_{3}$ and then $1.01 \mathrm{~g}$ amylase, $0.08 \mathrm{~g}$ trypsin, $0.12 \mathrm{~g}$ chymotryp$\sin , 1.71 \mathrm{~g}$ lipase and $0.94 \mathrm{~g}$ bile salt were added. The mixture was continuously mixed at $120 \mathrm{rpm}$ for $2 \mathrm{~h}$ at $37^{\circ} \mathrm{C}$.

The intestinal digestion samples were transferred to a 500 $\mathrm{ml}$ beaker and placed in a thermostat at $103{ }^{\circ} \mathrm{C}$ for $12 \mathrm{~h}$. After heating, samples were chemically analysed.

Statistical analysis (mean, standard deviation, correlation) was conducted with MS Excel 2016 and SPSS 19 software. All analyses were made in triplicate. Differences were considered statistically significant with a confidence level $p<$ 0.05 .

\section{RESULTS}

The results of determined protein, fat, $\beta$-glucans, starch, resistant starch, soluble and insoluble fibre and total sugar content in the hulless barley cultivar grains are summarised in Table 1.

The results showed that protein content significantly differed among cultivars $(p<0.05)$. The content of protein in the samples of hulless barley grains ranged from 14.42 to $18.19 \mathrm{~g} \cdot 100 \mathrm{~g}^{-1}$, and the protein richest cultivars were 'Pihl' and 'Kornelija'. The fat content of barley grains varied from 2.13 to $3.22 \mathrm{~g} \cdot 100 \mathrm{~g}^{-1}, \beta$-glucans varied from 4.17 to 6.59 $\mathrm{g} \cdot 100 \mathrm{~g}^{-1}$, and starch varied from 49.15 to $64.06 \mathrm{~g} \cdot 100 \mathrm{~g}^{-1}$. The highest content of $\beta$-glucans was found in the grains of 
Table 1. The chemical composition of different hulless barley cultivars

\begin{tabular}{|c|c|c|c|c|c|}
\hline \multirow[t]{3}{*}{ Traits } & \multicolumn{5}{|c|}{ Hulless barley cultivars } \\
\hline & Pihl & Gawrozs & CDC Hilose & CDC Ascent & Kornelija \\
\hline & \multicolumn{5}{|c|}{ Mean $\pm \mathrm{SD}$} \\
\hline Protein, g. $100 \mathrm{~g}^{-1}$ & $18.19^{\mathrm{a}} \pm 0.30$ & $14.42^{\mathrm{b}} \pm 0.25$ & $14.60^{\mathrm{b}} \pm 0.31$ & $14.59^{b} \pm 0.26$ & $17.76^{\mathrm{a}} \pm 0.26$ \\
\hline Fat, $\mathrm{g} \cdot 100 \mathrm{~g}^{-1}$ & $2.13^{\mathrm{c}} \pm 0.38$ & $2.56^{\mathrm{a}} \pm 0.38$ & $3.22^{\mathrm{a}} \pm 0.39$ & $2.97^{\mathrm{a}} \pm 0.38$ & $2.40^{\mathrm{ab}} \pm 0.38$ \\
\hline$\beta$-glucans, g.100 g ${ }^{-1}$ & $4.98^{b} \pm 0.25$ & $6.11^{\mathrm{a}} \pm 0.37$ & $6.19^{\mathrm{a}} \pm 0.51$ & $6.59^{\mathrm{a}} \pm 0.27$ & $5.61^{b} \pm 0.40$ \\
\hline Starch, g.100 g $\mathrm{g}^{-1}$ & $58.76^{\mathrm{a}} \pm 0.22$ & $58.51^{\mathrm{a}} \pm 0.31$ & $49.15^{\mathrm{b}} \pm 0.22$ & $64.06^{\mathrm{c}} \pm 0.27$ & $57.84^{\mathrm{d}} \pm 0.46$ \\
\hline Resistant starch, g.100 g ${ }^{-1}$ & $0.80^{c} \pm 0.12$ & $0.39^{\mathrm{d}} \pm 0.10$ & $10.65^{\mathrm{a}} \pm 3.33$ & $0.74^{\mathrm{c}} \pm 0.43$ & $0.88^{\mathrm{c}} \pm 0.30$ \\
\hline SDF, $g \cdot 100 \mathrm{~g}^{-1}$ & $24.1^{\mathrm{b}} \pm 4.8$ & $32.0^{\mathrm{a}} \pm 6.4$ & $28.3^{\mathrm{a}} \pm 5.7^{\mathrm{ab}}$ & $18.1^{\mathrm{c}} \pm 3.6$ & $23.3^{\mathrm{b}} \pm 4.7$ \\
\hline IDF, $\mathrm{g} \cdot 100 \mathrm{~g}^{-1}$ & $2.4^{\mathrm{c}} \pm 1.0$ & $0.7^{\mathrm{d}} \pm 0.3$ & $2.3^{c} \pm 0.9$ & $4.2^{\mathrm{a}} \pm 1.3$ & $3.2^{\mathrm{b}} \pm 0.8$ \\
\hline
\end{tabular}

Different letters in the same line represent statistically different results $(p<0.05)$.

SDF, soluble dietary fibre; IDF, insoluble dietary fibre

Table 2. Porridge composition and fermented porridge solids after simulated digestion process

\begin{tabular}{|c|c|c|c|c|c|c|c|}
\hline \multirow[t]{2}{*}{ Cultivar } & Dry matter & Protein & $\beta$-glucans & $\mathrm{RS}^{1}$ & $\mathrm{SDF}^{2}$ & $\mathrm{IDF}^{3}$ & FPS $^{4}$ \\
\hline & \multicolumn{7}{|c|}{$\mathrm{g}$ per portion } \\
\hline Pihl & 20.83 & 3.79 & 1.04 & 0.17 & 5.02 & 0.50 & 18.52 \\
\hline Gawrozs & 20.19 & 2.91 & 1.23 & 0.08 & 6.46 & 0.14 & 11.70 \\
\hline CDC Hilose & 20.11 & 2.94 & 1.24 & 2.14 & 5.69 & 0.46 & 16.92 \\
\hline CDC Ascent & 22.57 & 3.29 & 1.49 & 0.17 & 4.09 & 0.95 & 15.76 \\
\hline Irbe & 23.23 & 3.45 & 0.97 & 0.61 & 4.90 & 0.65 & 11.84 \\
\hline Correlation with FPS & - & 0.299 & 0.142 & 0.252 & 0.340 & 0.268 & - \\
\hline
\end{tabular}

RS, resistant starch; SDF, soluble dietary fibre; IDF, insoluble dietary fibre; FPS, fermented porridge solids

cultivars 'CDC Ascent', 'CDC Hilose', and 'Gawrozs' $6.59 \mathrm{~g} \cdot 100 \mathrm{~g}^{-1} ; 6.19 \mathrm{~g} \cdot 100 \mathrm{~g}^{-1}$ and $6.11 \mathrm{~g} \cdot 100 \mathrm{~g}^{-1}$, respectively. The highest content of resistant starch (10.65 g.100 $\mathrm{g}^{-1}$ ) was found in the samples of cultivar 'CDC Hilose'. The resistant starch content was at least four times higher than in cultivars 'Irbe' and others. Soluble dietary fibre in hulless barley grains varied from 18.1 to $32.0 \mathrm{~g} \cdot 100 \mathrm{~g} \mathrm{~g}^{-1}$ and the highest was observed in the grains of cultivar 'Gawrozs'. Insoluble dietary fibre content varied from 0.7 to $4.2 \mathrm{~g} \cdot 100$ $\mathrm{g}^{-1}$. The highest content of insoluble dietary fibre occurred in the samples of cultivar 'CDC Ascent'. The content of total sugars varied from 0.8 to $1.3 \mathrm{~g} \cdot 100 \mathrm{~g}^{-1}$ and the highest value occurred in the samples of cultivar 'CDC Hilose'.

The content of protein, $\beta$-glucans, soluble and insoluble dietary fibre and resistant starch per portion of porridge (30 g) and fermented porridge solids after in-vitro digestion are shown in Table 2.

The protein content in porridge portion varied from $2.91 \mathrm{~g}$ to $4.08 \mathrm{~g}$, the highest was in the porridge made from 'Kornelija' cultivar flakes. $\beta$-glucan content varied from 0.97 to $1.49 \mathrm{~g}$ per portion and cultivar 'CDC Ascent' flakes porridge was the richest in $\beta$-glucans. The highest amount of fermented porridge solids was found in cultivar 'Pihl' samples. The correlations between the individual compounds (proteins, $\beta$-glucans, resistant starch, soluble or insoluble fibre) and fermented porridge solids were calculated with the aim to compare the impact of the examined components on digestion process. The results (Table 2) showed that all correlations were weak. The highest correlation (0.340) was observed between soluble dietary fibre and digested flakes solids.

The protein and $\beta$-glucan content in the digested porridge portions is shown in Figures 1 and 2.

The content of protein after porridge digestion in vitro (Fig. 1) ranged from 2.47 to $3.83 \mathrm{~g}$ per portion, and the content of $\beta$-glucans after in vitro digestion (Fig. 2) ranged from 0.04 to $0.29 \mathrm{~g}$ per portion.

\section{DISCUSSION}

Hulless barley cultivars analysed in this study were characterised by a rather high protein content. Protein content of cultivars 'Pihl' and 'Kornelija' exceeded $17.5 \mathrm{~g} \cdot 100 \mathrm{~g}^{-1}$, which confirmed a significant effect of genotype on protein variation of this trait. A previous study (Sturite et al., 2018) study confirmed that hulless barley cultivar 'Kornelija' followed by 'Pihl' had the highest protein content, also our study showed that high protein content $(p<0.05)$ could also be obtained from cultivars 'Pihl' and 'Kornelija'.

The total protein content of barley grains was $8-13 \%$. In various barley grain tissues, specific types of protein occur 


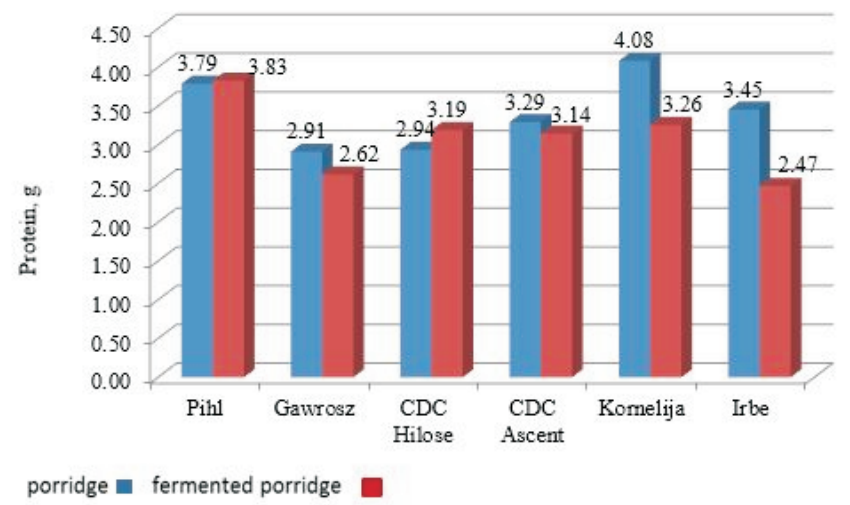

Fig. 1. The content of protein in samples before and after digestion.

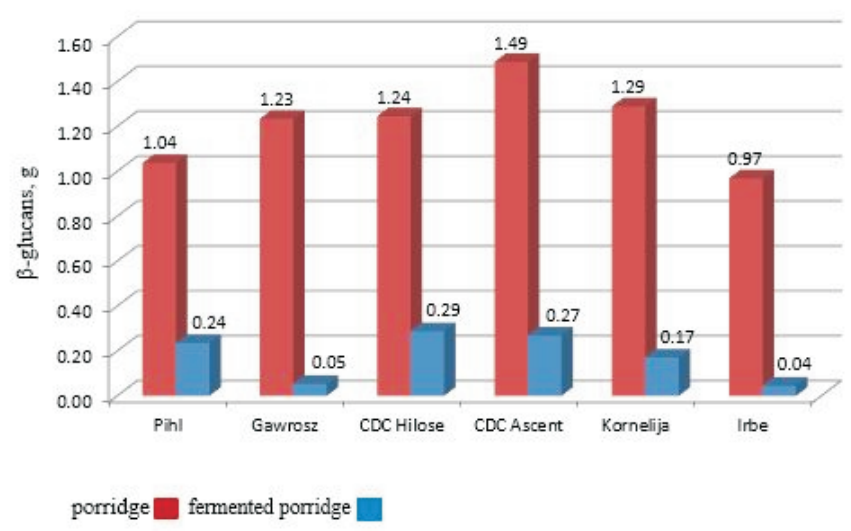

Fig. 2. The content of $\beta$-glucans in samples before and after digestion.

at different levels (Wang et al., 2010). Barley proteins, mainly albumin, can notably deactivate $\alpha$-amylase activity and slow starch digestibility (Yu, 2018). The interaction of proteins with starch and the breakdown of proteins during digestion can significantly increase the reduced starch amount in grains.

Starch mainly consists of amylose and amylopectin. The proportion of amylose and amylopectin vary in different cereals, but in general starch consists of $25 \%$ amylose and 75 $\%$ amylopectin (Newman, Newman, 2008). "Waxy Barley" consists of up to $100 \%$ of amylopectin. There are also different cultivars that have a high content of amylose, around 40-60\%. Two accessions with modified starch composition, such as high amylose barley cultivar 'CDC Hilose' and low amylose barley cultivar 'CDC Ascent' (Ames et al., 2006) have higher levels of both protein and $\beta$-glucans. High amylose barley usually has high levels of resistant starch. Harris (2019) reported that the highest content of resistant starch was found in cultivar 'CDC Hilose'. The results of our study are in line with study of Djurle et al. (2016), where resistant starch was present in hulless barley flour $(0.9 \%$ in dry matter) of the high amylose cultivar 'Karmose'. The levels of resistant starch in low amylose barley and in high amylose barley cultivars were reported to be $0.4 \mathrm{~g} \cdot 100 \mathrm{~g}^{-1}$ and $1.6 \mathrm{~g} \cdot 100 \mathrm{~g}^{-1}$, respectively (Patterson, 2020).
Some forms of starch pass through the small intestines undigested. The term "resistant starch" refers to dietary fibre, which was previously known as the non-digestible components of plant cell walls (Englyst and Cummings, 1985). Resistant starch is a broad category that encompasses several structurally different starches. While all of them resist digestion by human enzymes, resistant starch has a different effect on the microbiota (Blenner et al., 2020). Resistant starch has the ability to attenuate acute postprandial responses when rapidly digestible carbohydrate sources are replaced (Harris, 2019).

The content of fermented porridge solids after in vitro digestion differed (Table 2), which can be explained by physical, chemical and structural differences among barley cultivars. The size of grains determines size of flakes, and firmness and water holding capacity of cultivars affect the size of particles in porridge. The rate at which compounds are digested is determined by a number of factors, including the rate at which proteins, fats, carbohydrates leave the gastric phase and become available for absorption and also by the diffusion of released compounds occur from food matrices (Khoury et al., 2012)

Since samples were not homogenised before digestion in vitro, there was different enzyme exposure for each sample or compound. The hydration properties of dietary fibre are related to the chemical structure of the polysaccharides, and other factors such as porosity, particle size, ionic form and strength, and in addition, the ability of dietary fibre to hold water is strongly related to the source of the dietary fibre (Elleuch, 2010).

We concluded that amount and composition of fermented porridge solids were related to the amount and structure of resistant starch, $\beta$-glucans, soluble and insoluble fibre in the studied hulless barley cultivars. We found that each fibre constituent had low impact on fermented porridge solids, as shown by correlation analysis (Table 2). The strongest impact on fermented amount was calculated for soluble dietary fibre $(0.340)$ followed by protein, insoluble dietary fibre, and specific fibre representatives - resistant starch and $\beta$-glucans with correlation coefficients $0.299 ; 0.268 ; 0.252$, and 0.142 , respectively. The impact of soluble fibre can be explained by their ability to form gels that delay gastric emptying, inhibit nutrient absorption and bile acid binding; altogether this may contribute to a decreased postprandial glycaemic response and a reduction in body cholesterol stores due to increased synthesis of new bile salts from cholesterol in the liver (Dikeman and Fahey, 2006).

The content of $\beta$-glucans after porridge fermentation varied among samples, as $\beta$-glucans are not homogenous compounds and different cultivars have different $\beta$-glucans composition. Since $\beta$-glucans can be soluble, and each form of insoluble fibre is characterised by a different fermentation pattern. A previous study reported that about $95 \%$ of oat water-extractable $\beta$-glucan was metabolised within the first $8 \mathrm{~h}$ of fermentation (Brahma et al., 2017). $\beta$-glucans are not completely released for the bioaccessibility (Mosele 
et al., 2018), which can limit bioavailability in the upper gastrointestinal tract as $\beta$-glucans are retained in the indigested residue.

The amount of protein in fermented porridge solids (Fig. 2) was the same as before fermentation. This can be explained by typically low digestibility of cereal proteins due to both external and internal factors. Examples of external factors are physical inaccessibility, cell structures and anti-nutritional factors, and some internal factors are amino acids sequences and crosslinking of proteins (Joye, 2019).

In addition to dietary proteins, the body also digests 50-100 g of endogenous proteins, which are excreted in the gastrointestinal lumen. The mixture (saliva, stomach juice, pancreatic enzymes, etc) is efficiently digested and absorbed in duodenum the first and shortest part of the small intestine, with a loss of approximately $1.6 \mathrm{~g}$ of nitrogen in the faeces each day, equivalent to $10 \mathrm{~g}$ of protein. Most of the lost nitrogen is used by the colon microflora for its growth and is therefore found in the stool as part of the bacterial mass (Erickson et al., 1990).

In general, this study confirmed that differences of hulless barley cultivars in chemical composition affect digestion and bioavailability of released nutrients in the gastrointestinal tract.

\section{CONCLUSIONS}

The content of protein, $\beta$-glucans, and resistant starch, soluble and insoluble dietary fibre significantly differed among hulless barley cultivars, and in vitro digestion results confirmed the same tendency. The digestion and bioavailability of released nutrients in the gastrointestinal tract are effected by differences among hulless cultivars in its chemical composition.

The amount of protein after in vitro digestion was not significantly decreased due to low digestibility of cereal protein, but the $\beta$-glucans concentration was significantly changed compared to non-digested samples.

\section{ACKNOWLEDGEMENTS}

The study of barley technological traits was co-financed by the ERDF project "The Hulless Barley Variety 'Kornelija' - High-Quality Wholegrain Raw Material for Developing Niche and Functional Products”, No. KC-PI-2017/43.

Thanks to Aaron Bhatty, Stein Bergersen, Henryk J. Czembor, and Pawet Cz. Czembor for providing seed of hulless barley accessions.

\section{REFERENCES}

Ahmad, A., Anjum, F. M., Zahoor, T., Nawaz, H., Dilshad, S. M. (2009). Extraction of $\beta$-glucan from oat and its interaction with glucose and lipoprotein profile. Pakistan J. Nutr., 8, 1486-1492.
Ahmad, A., Anjum, F. M., Zahoor, T., Nawaz, H., Dilshad, S. M. (2012). $\beta$-glucan: A valuable functional ingredients in foods. Crit. Rev. Food Sci. Nutr., 52, 2011-2012.

Ames, N., Rhymer, C., Rossnagel, B., Therriean, M., Ryland, D., Dua, S., Ross, K. (2006). Utilisation of diverse hulless barley properties to maximize food product quality. Cereal Food Sci., 51 (1), 23-28.

Baik, B. K., Ullrich, S. E. (2008). Barley for food: Characteristics, improvement, and renewed interest. J. Cereal Sci., 48, 233-242.

Biel, W., Bobko, K., Maciorowski, R. (2009). Chemical composition and nutritive value of husked and naked oats grain. J. Cereal Sci., 49, 413-418.

Brahma, S., Weier, S. A., Rose, D. J. (2017). Moisture content during extrusion of oats impacts the initial fermentation metabolites and probiotic bacteria during extendended fermentation by human fecal microbiota. Food Res. Int., 91, 209-214.

Brumovsky, L. A., Brumovsky, J. O., Fretes, M. R., Peralta, J. M. (2009). Quantification of resistant starch in several starch sources treated thermally. Int. J. Food Properties, 12 (3), 451-460.

Casterline, J. L. J., Oles, C. J., Ku, Y. (1997). In vitro fermentation of various food fiber fractions. J. Agricult. Food Chem., 45, 2463-2467.

Dongowski, G., Huth, M., Gebhard, E., Flamme, W (2002). Dietary fiber-rich barley products beneficial affected the intestine tracts of rats. $J$. Nutr., 132, 3704-3714.

Ehrenbergerova, J., Vaculova, K., Psota, V., Havlova, P., Serhantova, V. (2003). Effects of cropping system and genotype on variability in important phytonutrients content of the barley grain for direct food use. Plant Soil Environ., 49,443-450.

Englyst, H. N., Cummings, J. H. (1985). Digestion of the polysaccharides of some cereal foods in the human small intestine. Amer. J. Clin. Nutr., 42 , $778-787$.

Elleuch, M., Bedigian, D., Roiseux, O., Besbes, O., Blecker, C., Attia, H. (2010). Dietary fibre and fibre-rich by-products of processing: characterisation, technological functionality and commercial applications: A review. Food Chem., 124 (2), 411-421.

Erickson, R. H., Young, S., Kim, M. D. (1990). Digestion and absorbtion of of dietary protein. Annu. Rev. Med., 41, 133-139.

EFSA - European Food Safety Authority (2010). Scientific opinion on dietary reference values for carbohydrates and dietary fiber. EFSA J., 8, 1462.

FDA - Food and Drug Administration, Department of Health and Human Services (2005). Food labeling: health claims: Soluble dietary fiber from certain foods and coronary heart disease. Interim final rule. Fed. Regist., 70, 76150-76162.

Izydorczyk, M. S., Dexter, J. E. (2008). Barley $\beta$-glucans and arabinoxylans: Molecular structure, physicochemical properties, and uses in food products: A review. Food Res. Int., 41, 850-868.

Izydorczyk, M. S., McMillan, T., Bazin, S., Kletke, J., Dushnicky, L., Dexter, J., Chepurna, A., Rossnagel, B. (2014). Milling of Canadian oats and barley for functional food ingredients: Oat bran and barley fibre-rich fractions. Canadian J. Plant Sci., 94, 573-586.

Harris, K. F. (2019). An introductory review of resistant starch type 2 from high-amylose cereal grains and its effect on glucose and insulin homeostasis. Nutr. Rev., 77 (11), 748-764.

Henningsson, Å., Björck, I., Nyman, M. (2001). Short-chain fatty acid formation at fermentation of indigestible carbohydrates. Scand. J. Nutr., 45, $165-168$.

Jenkins, A. L., Jenkins, D. J. A., Zdravkovic, U., Wursch, P., Vuksan, V. (2002). Depression of the glycaemic index by high levels of beta-glucan fiber in two functional foods tested in type 2 diabetes. Eur. J. Clin. Nutr., 56, $622-628$.

Joye, I. (2019). Protein digestibility of cereal products. Foods, 8 (6), 199. 
Kalra, S., Jood, S. (2001). Effect of dietary barley $\beta$-glucan on cholesterol and lipoprotein fractions in rats. J. Cereal Sci., 31, 141-145.

Minekus, M., Alminger, M., Alvito, P., Balance, S., Bohn, T., Bourlieu, C. Carriere, F., Boutrou, R., Corredig, M., Dupont, D., et al. (2014). A standardised static in vitro digestion method suitable for food: An international consensus. Food Funct., 5, 1113-1124.

Mosele, J. I., Motilva, M. J., Ludwig, I. A. (2018). Beta-glucan and phenolic compounds: Their concentration and behaviour during in-vitro gastrointestinal digestion and colonic fermentation of different barley-based food products. J. Agric. Food. Chem., 66 (34), 8966-8975.

Newman, R. K., Newman, C. W. (2008). Barley: Genetics and nutrient composition. In: Barley for Food and Health. Science, Technology and Products. John Wiley\&Sons, pp. 56-94.

Patterson, M. A., Maiya, M., Stewart, M. L (2020). Resistant starch content in foods commonly consumed in the United States: A narrative review. $J$. Acad. Nutr. Dietetics, 120 (2) 230-243.

Received 22 March 2021

Accepted in the final form 10 November 2021
Rose, D. J., DeMeo, M. T., Keshavarzian, A., Hamaker, B. R. (2007). Influence of dietary fiber on inflammatory bowel disease and colon cancer: Importance of fermentation pattern. Nutr. Rev., 65 (2), 51-62.

Sterna, V., Zute, S., Jansone, I., Kantane, I. (2017). Chemical composition of covered and naked spring barley varieties and their potential for food production. Polish J. Food Nutr. Sci., 67 (2), 151-155.

Sturite, I., Kronberga, A., Strazdina, V., Kokare , A., Aassveen, M., Kari, A., Bergjord O., Sterna, V., Straumite, E. (2018). Adaptability of hull-less barley varieties to different cropping systems and climatic conditions, Acta Agriculturae Scandinavica, Section B - Soil \& Plant Science, 69, 1-11.

Wood, P. J., Arrigoni, E. Shea Miller, S., Amado, R. (2002). Fermentability of oat and wheat fractions enriched in $\beta$-glucan using human fecal inoculation. Cereal Chem., 79, 445-454.

Wood, P. J. (2002). Relationships between solution properties of cereal $\beta$-glucans and physiological effect: A review. Trends Food Sci. Technol., 13, 313-320.

Yu, W., Zou, W., Dhtal, S., Wu, P., Gidley, M., Fox, G. P., Gilbert R. G. (2017). The adsorption of $\alpha$-amylase on barley proteins affects the in vitro digestion of starch in barley flour. Food Chem., 24, 493-501.

\section{KAILGRAUDU MIEŽU ŠḲIRṆU PĀRSLU FERMENTĀCIJAS IZPĒTE IN VITRO}

Mieži (Hordium vulgare L.) ir nozīmīgi pārtikā, jo satur uzturā svarīgos $\beta$-glikānus, olbaltumvielas, rezistento cieti, fenola savienojumus u.c. $\beta$-glikāns pazemina holesterīna līmeni asins plazmā un glikēmisko indeksu, uzlabo lipīdu metabolismu, kā arī samazina risku saslimstībai ar resnās zarnas vēzi. Kailgraudu miežu škirnes ir uzturvielām bagātākas, piemērotākas uzturam, kā arī efektīvas pārstrādei, jo nepieciešama tikai minimāla pirmapstrāde. Vairāki pêtīijumi apliecina, ka kailgraudu miežiem ir augstāka sagremojamība, tajos ir lielāks olbaltumvielu saturs, salīdzinot ar plēkšņu miežiem. Lai gan dažādām šķirnēm ir unikāls sastāvs un fizikālās īpašības, kailgraudu mieži joprojām ir maz pētīti. Šĩ pētījuma mērkis bija novērtēt dažādu kailgraudu miežu škirṇu pārslu fermentāciju in vitro un analizēt miežu $\beta$-glikānu un olbaltumvielu sagremojamību. Pētījumam tika sagatavotas sešu kailgraudu miežu škirṇu pārslas ar atškirīgu $\beta$-glikānu (4,17-6,59\%), šḳīstošo šķiedrvielu (18,1-32,0\%) un rezistentās cietes $(0,74-10,65 \%)$ saturu. Pārslas vārītas 10 minūtes ūdenī bez sāls, iegūstot biezputru paraugus, kas izmantoti tālākai fermentācijai in vitro. Paraugiem pēc fermentācijas tika noteikts sausnas saturs, arī $\beta$-glikānu un olbaltumvielu saturs sausnā. Nesagremotās sausnas saturs būtiski atškīīās dažādu miežu škirṇu pārslu paraugos, tas svārstījās no 30,3 līdz 61,0\%. Savukārt olbaltumvielu saturā būtiskas atškirīibas netika konstatētas, ievērtējot miežu olbaltumvielu sagremošanas īpatnības gremošanas fermentu ietekmē. Ievērojami atškīinās $\beta$-glikānu saturs, apstiprinot šḳistošās frakcijas lielāku īpatsvaru miežu paraugos. 